\title{
CYP1A1, GSTM1, GSTT1 and GSTP1 polymorphisms in an Afro-Brazilian group
}

\author{
Kátia Kvitko, Pedro de Abreu Gaspar, Martiela Ribeiro Torres and Mara H. Hutz \\ Departamento de Genética, Instituto de Biociências, Universidade Federal do Rio Grande do Sul, \\ Porto Alegre, RS, Brazil.
}

\begin{abstract}
Gene polymorphisms involved in the metabolism of drugs and chemical carcinogens seem to be responsible for differences in the susceptibility of individuals to cancer, but genetic population studies are needed to characterize these polymorphisms in different ethnic populations. We investigated polymorphisms of the cytochrome P450 (CYP) gene CYP1A1 and the glutathione S-transferase (GSTs) genes GSTM1, GSTT1 and GSTP1 in a sample of AfroBrazilians from the southern Brazilian city of Porto Alegre to verify if there were ethnic differences compared to the polymorphisms of the same genes in a previously described sample of Brazilians of European descent from the same city. The allele frequencies detected in the Afro-Brazilian population investigated in this study were CYP1A1*2A (30\%) and GSTP1*Val (42\%) while the frequency of the GSTM1 null genotype was $34 \%$ and that of the GSTT1 null genotype was $28 \%$. Significant differences in genotype distribution and allelic frequencies were detected between Brazilians of African and of European descent from Porto Alegre in terms of the polymorphisms CYP1A1*2A ( $p=0.003)$, GSTP1-lle105Val $(p=0.002)$ and the GSTM1 null genotype $(p=0.01)$ but there was no detectable significant difference in respect to GSTT1 null genotype frequencies
\end{abstract}

Key words: African, Brazilian, CYP1A1, European, GSTs, Porto Alegre.

Received: December 20, 2005; Accepted: February 14, 2006.

The metabolism of drugs and chemical carcinogens involves a variety of isoenzymes such as members of the Cytochrome P450 (CYP) and Glutathione S-transferase (GSTs) families, with the polymorphisms described in these genes appearing to be responsible for differences in individual susceptibility to cancer (Perera and Weinstein, 2000; Miller et al., 2002; Norppa, 2003). Environmental factors are important contributors to human carcinogenesis and the risk of cancer is strongly influenced by genetic differences related to ethnic propensity to develop cancer. Epidemiological studies have shown that some kinds of tumors (e.g. breast, lung, prostate, etc.) are more prevalent in European-derived population samples. This higher prevalence of tumors has also been reported in the population of the southernmost Brazilian state of Rio Grande do Sul (RS) according to data from the Rio Grande do Sul Health Secretariat Cancer Registry (Secretaria da Saúde do Estado do Rio Grande do Sul, Registro de câncer de base populacional de Porto Alegre, http://www.saude.rs.gov.br).

Genes involved in the metabolism of carcinogens may be used as markers of individual susceptibility to can-

Send correspondence to Kátia Kvitko. Departamento de Genética, Universidade Federal do Rio Grande do Sul, Caixa Postal 15053, 91501-970 Porto Alegre, RS, Brazil. E-mail: katia.kvitko@ ufrgs.br. cer since differential activity of these enzymes may increase or decrease the activity of xenobiotics. These enzymes are responsible for the activation (phase I reactions) or deactivation (phase II reactions) of carcinogens. Phase I enzymes such as those of the $C Y P$ gene family may convert harmless chemicals into electrophilic compound via oxidation reactions while phase II enzymes, such as those belonging to the GSTs gene family, detoxify carcinogenic metabolites to extractable hydrophilic products and remove the activated compound by way of conjugation reactions (Perera and Weinstein, 2000; Norppa, 2003).

The capital of Rio Grande do Sul state (population $\approx 11$ million) is Porto Alegre, a city of about 3 million people of which the Brazilians of European descent are still mainly of Portuguese descent, although individuals of Italian, Spanish and German ancestry have also contributed to the gene pool. About $14 \%$ of the Porto Alegre population is constituted of Afro-Brazilians who are mainly descendants of slaves brought to Brazil between the 15th and 18th centuries, mainly from the West Coast of Africa but also from Angola and Mozambique (Bortolini et al., 1997; IGBE, 2000). In Brazil skin color is often seen as equivalent to race, resulting in a complex and subjective evaluation of ethnicity. The Brazilian Institute of Geography and Statis- 
tics (Instituto Brasileiro de Geografia e Estatística, IBGE) classifies Brazilians into five ethnic groups according to the prevalence of the ethnic group in the general Brazilian population as 53\% White, 38\% Brown, 6\% Black and 3\% Yellow or Amerindian (IBGE, 2000). However, in Rio Grande do Sul the proportion is $87.5 \%$ White, $7 \%$ Brown, $5 \%$ Black and $0.2 \%$ Yellow or Amerindian (IBGE, 2000). According to Bortolini and Pena (2004) the expression of 'Afro-descendent' has recently been incorporated into the ethnic semantic concerning the extent of admixture in Brazil. These authors also point out that, independent of the criteria chose, it is still difficult to place people into distinct ethnic groups.

Gaspar et al., (2002) were the first to investigate polymorphisms related to carcinogen metabolism in AfroBrazilians from Porto Alegre, when they compared samples of Brazilians of African and of European descent from Porto Alegre in respect to $C Y P 1 A 1 * 2 C$ polymorphisms and found high $C Y P 1 A 1 * 2 C$ allele frequencies in both groups as compared to populations from other parts of the world, although the differences between the Porto Alegre groups were not statistically significant.

The aim of this study described in our current paper was to investigate the frequency of $C Y P 1 A 1 * 2 A$, GSTP1Ile105 Val, GSTM1 and GSTT1 gene polymorphisms in an Afro-Brazilian sample from Porto Alegre to ascertain if these polymorphisms show ethnic differences compared to data (Gaspar et al., 2004) for Brazilians of European descent from Porto Alegre. We also compared the frequencies detected in this study with some other Brazilian populations. The UFRGS ethics committee approved this study and all subjects signed an informed consent form to participate in this investigation.

The sample of Afro-Brazilians ( $\mathrm{n}=100$; mean age $=$ 38 years; $68 \%$ males) investigated consisted of patients from the Central Laboratory of a general Public Hospital (Santa Casa de Misericórdia de Porto Alegre to which they had been referred to for routine blood examinations and who had been classified as Afro-Brazilians based on skin color and ancestry.

Genomic DNA was isolated from whole blood by the salting out method and four polymorphic markers investigated by genotyping using the polymerase chain reactionrestriction fragment length polymorphism (PCR-RFLP) method. The $C Y P 1 A 1 * 2 A$ allele was genotyped using the procedure of Hayashi et al. (1991) and detected after digestion with MspI. The GSTM1, GSTT1 and GSTP1 genes were genotyped using a multiplex PCR method and a reaction mixture consisting of $100 \mathrm{ng}$ of genomic DNA, 15 pmol of each primer, $10 \mathrm{mM}$ Tris $\mathrm{HCl}, 4.5 \mathrm{mM} \mathrm{MgCl}_{2}$, $50 \mathrm{mM} \mathrm{KCl}, 100 \mathrm{mM}$ dNTPs and 1 unit of Taq DNA polymerase in a total volume of $50 \mu \mathrm{L}$. The amplification protocol consisted of initial denaturation at $94{ }^{\circ} \mathrm{C}$ for $5 \mathrm{~min}$, 6 touchdown cycles of $1 \mathrm{~min}$ at $94^{\circ} \mathrm{C}$ followed by 2 min at $59^{\circ} \mathrm{C}$ (decreasing to $54{ }^{\circ} \mathrm{C}$ at a rate of $1{ }^{\circ} \mathrm{C}$ per cycle) and
1 min at $72{ }^{\circ} \mathrm{C}$, and 30 cycles at $94^{\circ} \mathrm{C}$ for 1 min followed by $1 \mathrm{~min}$ at $55^{\circ} \mathrm{C}$ and $1 \mathrm{~min}$ at $72^{\circ} \mathrm{C}$, plus a final extension of 5 min at $72{ }^{\circ} \mathrm{C}$. An aliquot of the amplification product was subjected to horizontal agarose gel $(3.5 \%$, w/v) electrophoreses to verify the presence or absence of GSTM1 and GSTT1 fragments, the GSTP1 product being used as a control for this reaction. Primer sequences were those reported by Harries et al. (1991), Bell et al. (1993) and Pemble et al. (1994). A second aliquot of the amplified GSTP1 product was digested with BsmaI as described by Harris et al. (1991).

Allelic frequencies were estimated by gene counting. Comparisons among allelic and genotype frequencies were performed using the PEPI software program (Abramson, 2004). Agreement of genotypic frequencies with HardyWeinberg expectations was evaluated using the $\chi^{2}$ test of Roff and Bentzen (1989) and Fisher's exact test (Beiguelman, 1988). Haplotypes estimates and pairwise linkage disequilibrium tests were performed using the PHASE program version 2.0 (Stephens et al., 2001; Li and Stephens, 2003).

The genotype distributions and allele frequencies detected in this study are shown in Table 1. Although there was no deviation from the expected Hardy-Weinberg frequencies there were significant differences in genotype distribution and allelic frequencies between Afro-Brazilians and Brazilians of European descent in respect of the frequency of the CYP1A1*2A (p=0.003) and GSTP1Ile105Val $(\mathrm{p}=0.002)$ polymorphisms and of the GSTM1

Table 1 - The CYP1A1, GSTM1, GSTT1 and GSTP1 genotype and allele frequencies (\%) in Euro-Brazilians and African-Brazilians from Porto Alegre, Rio Grande do Sul, Brazil. Allele frequencies are shown in bold.

\begin{tabular}{|c|c|c|}
\hline \multirow{2}{*}{$\begin{array}{l}\text { Allele (in bold) or } \\
\text { genotype }\end{array}$} & \multicolumn{2}{|c|}{ Ethnicity } \\
\hline & $\begin{array}{l}\text { Afro-Brazilians } \\
\qquad(\mathrm{n}=100)\end{array}$ & $\begin{array}{l}\text { Euro-Brazilians }^{1} \\
\qquad(\mathrm{n}=90)\end{array}$ \\
\hline \multicolumn{3}{|l|}{$C Y P 1 A 1 * 2 A$} \\
\hline$* 1 A / * 1 A$ & 47.0 & 71.1 \\
\hline$* 1 A / * 2 A$ & 45.0 & 23.3 \\
\hline$* 2 A / * 2 A$ & 8.0 & 5.6 \\
\hline$C Y P 1 A 1 * 2 A$ & $0.30^{2}$ & $0.166^{2}$ \\
\hline GSTM1 null genotype & $34.0^{3}$ & $50.0^{3}$ \\
\hline GSTT1 null genotype & 28.0 & 21.1 \\
\hline \multicolumn{3}{|l|}{ GSTP1 genotypes } \\
\hline Ile/Ile & 29.0 & 52.2 \\
\hline Ile/Val & 58.0 & 40.0 \\
\hline $\mathrm{Val} / \mathrm{Val}$ & 13.0 & 7.8 \\
\hline GSTP1 * Val & $0.420^{4}$ & $0.278^{4}$ \\
\hline
\end{tabular}

${ }^{1}$ From Gaspar et al. (2004).

${ }^{2}$ Allelic and genotype frequencies differ $\left(\chi^{2}\right.$ test, $\left.p=0.003\right)$.

${ }^{3}$ Genotype frequency differs $\left(\chi^{2}\right.$ test, $\left.p=0.01\right)$.

${ }^{4}$ Allelic and genotype frequencies differ $\left(\chi^{2}\right.$ test, $\left.\mathrm{p}=0.002\right)$. 
null genotype $(p=0.01)$ but there were no detectable difference between the two groups for the GSTT1 null genotype. Some studies have pointed out ethnic differences in genotype frequencies of CYPIA1 and GSTs family polymorphisms and these polymorphisms may be responsible for differences in individual susceptibility to carcinogens (Perera and Weinstein, 2000, Norppa, 2003).

Polymorphisms of the CYPIA1 gene have been detected in some population studies and the frequency and type of polymorphism have been associated with susceptibility to cancer and have shown ethnic correlations (Garte, 1998). The $C Y P 1 A 1 * 2 A$ homozygous variant genotype has been detected at higher frequencies in Asians (11-13\%) and African-Americans (6-7\%) but at lower frequencies in Northern Europeans and European-Americans (0-2\%) (Crofts et al., 1993; Raunio et al., 1995). In our study, $8 \%$ of the Porto Alegre Afro-Brazilians studied showed the rare CYP $1 A 1 * 2 A$ homozygous genotype as compared to the $5.6 \%$ reported by Gaspar et al. (2004) for Brazilians of European descent, these ethnic differences being similar to those detected when Europeans, European-Americans and African-Americans populations were compared (Crofts et al., 1993; Raunio et al., 1995). Furthermore, in a breast cancer study Amorim et al. (2002) also described higher frequencies of the variant $C Y P 1 A 1 * 2 A$ genotype in a nonwhite ethnic sample than in an ethnically white sample from the Brazilian city of Rio de Janeiro.

The higher frequencies of $C Y P 1 A 1 * 2 A$ polymorphism detected in our two Porto Alegre groups compared to frequencies of the same polymorphism described for populations of African (6-7\%, Crofts et al., 1993) and European (0-2\%; Raunio et al., 1995) descent may have been due to the ethnic admixture described for Brazilian populations because our Porto Alegre Afro-Brazilian group showed 59\% European admixture while our European-Brazilian group showed $7.8 \%$ African admixture based on the reports of various studies (Bortolini et al., 1997; Bortolini and Penna, 2004; Franco et al., 1982). The CYP1A1*2C polymorphism studied by Gaspar et al. (2002) also showed higher frequencies in Porto Alegre than that described for other populations.

The GSTM1 and GSTT1 null genotype frequencies for our Porto Alegre Afro-Brazilian sample were similar to those described for other Afro-Brazilian populations (Amorim et al., 2002; Rossini et al., 2002; Gattás et al., 2004) which themselves are similar to the frequencies described for other (non-Brazilian) Afro-descend populations (Harries et al., 1991, Bailey et al., 1998). These studies have also detected significant differences in the frequency of GSTM1 polymorphisms among Afro-Brazilians and Brazilians of European descent (Amorim et al., 2002; Rossini et al., 2002; Gattás et al., 2004).

We also analyzed the frequency of $C Y P 1 A 1 * 2 B$ haplotypes (i.e. haplotypes involving combinations of the $* 2 A / 2 C$ polymorphism. See http:// www.imm.ki.se/
CYPalleles/cyp1a1.htm for CYP1A1 allele nomenclature) in Afro-Brazilians and Brazilians of European descent and found linkage disequilibrium (D) to be 0.85 for Brazilians of European descent but zero (i.e. no linkage) the AfroBrazilian group.

The GSTP1-Ile105 Val polymorphism frequency described in this article is similar to those described for other populations by Harris et al. (1991). In our study we also detected ethnic differences in genotype distribution and allelic frequencies between Afro-Brazilians and Brazilians of European descent in respect of this polymorphism. However, Rossini et al., (2002) studied Rio de Janeiro samples and detected the GSTP1 $\mathrm{Val} / \mathrm{Val}$ homozygous genotype more frequently in ethnically white individuals than in non-white individuals, which is at variance with our results and merits further investigation.

\section{Acknowledgments}

Financial support was provided by the Programa de Apoio a Núcleos de Excelência (PRONEX), Conselho Nacional de Desenvolvimento Científico e Tecnológico (CNPq), Financiadora de Estudos e Projetos (FINEP) and the Fundação de Amparo à Pesquisa do Estado do Rio Grande do Sul (FAPERGS).

\section{References}

Abramson JH (2004) WINPEPI (PEPI-for-windows): Computer programs for epidemiologists. Epidemiologic Perspectives and Innovations 1:6.

Amorim LMFA, Rossini A, Mendonça GAS, Lotsch PF, Simão TA, Gallo CVM and Pinto LFR (2002) CYP1A1, GSTM1, and GSTT1 polymorphisms and breast cancer risk in Brazilian women. Cancer Lett 181:179-186.

Bailey LR, Roodi N, Verrier CS, Yee CJ, Dupont WD and Parl FF (1998) Breast cancer and CYPIA1, GSTM1, and GSTT1 polymorphisms: evidence of a lack of association in Caucasians and African Americans. Cancer Res 58:65-70.

Beiguelman B (1988) Curso Prático de Bioestatística. Sociedade Brasileira de Genética, Ribeirão Preto, 231 pp.

Bell DA, Taylor JA, Paulson DF, Robertson CN, Mohler JL and Lucier GW (1993) Genetic risk and carcinogen exposure: A common inherited defect of the carcinogen-metabolism gene glutathione S-transferase M1 (GSTM1) that increases susceptibility to bladder cancer. $\mathrm{J}$ Natl Cancer Inst 85:1159-1164.

Bortolini MC and Pena SD (2004). Pode a genética definir quem pode se beneficiar das cotas universitárias e demais ações afirmativas? Estudos Avançados, 18:1-22.

Bortolini MC, Weimer TA, Salzano FM, Moura LB and Silva MCBO (1997) Genetic structure of two urban AfroBrazilian populations. Int J Phys Anthropol 12:5-16.

Crofts F, Cosma GN, Currie D, Taiol E, Toniolo P and Garte S (1993) A novel CYP1A1 gene polymorphism in African-Americans. Carcinogenesis 14:729-1731.

Franco MHLP, Weimer TA and Salzano FM (1982) Blood polymorphism and racial admixture in two Brazilian populations. Am J Phys Anthropol 58:127-132. 
Garte S (1998) The role of ethnicity in cancer susceptibility gene polymorphism: The example of CYP1A1. Carcinogenesis 19:1329-1332.

Gaspar PA, Kvitko K, Papadópolis LG, Hutz MH and Weimer TA (2002) High frequency of CYP1A1*2C allele in Brazilian populations. Hum Biol 74:235-242.

Gaspar PA, Moreira J, Kvitko K, Torres MR, Moreira A and Weimer TA (2004) CYP1A1, CYP2E1, GSTM1, GSTT1, GSTP1, and TP53 polymorphisms: Do they indicate susceptibility to chronic obstructive pulmonary disease and nonsmall-cell lung cancer? Genet Mol Biol 27:133-138.

Gattás GJF, Kato M, Soares-Vieira JA, Siraque MS, Kohler P, Gomes L, Rego MAV and Bydlowski SP (2004) Ethnicity and glutathione S-transferase (GSTM1/GSTT1) polymorphisms in a Brazilian population. Braz J Med Biol Res 37:451-458.

Harries LW, Stubbins MJ, Forman D, Howard GC and Wolf CR (1991) Identification of genetic polymorphisms at the glutathione S-transferase Pi locus and association with susceptibility to bladder, testicular, and prostate cancer. Carcinogenesis 18:641-644.

Hayashi S, Watanabe J, Nakachi K and Kawajiri K (1991) Genetic linkage of lung cancer-associated MpsI polymorphism with amino acid replacement in the heme binding region of the human cytochrome P4501A1 gene. J Biochem 110:407-411.

Instituto Brasileiro de Geografia e Estatística (2000) Censo demográfico 2000. Características gerais da população. Resultado da amostra. Available in: http:/www.ibge.gov.br/home/ estatistica/populacao/censo2000/populacao/censo2000 populacao.pdf (March/2004).
Li N and Stephens M (2003) Modeling linkage disequilibrium, and identifying recombination hotspots using SNP data. Genetics 165:2213-33.

Miller PD, Liu G, De Vivo I, Lynch TJ, Wain JC, Su L and Christiani DC (2002) Combinationof the variant genotype of GSTP1, GSTM1 and, p53 are associated with an increased lung cancer risk. Cancer Res 62:2819-2823.

Norppa H (2003) Genetic susceptibility, biomarkers response, and cancer. Mutat Res 544:339-348.

Perera FP and Weinstein IB (2000) Molecular epidemiology: Recent advances and future directions. Carcinogenesis 21:517-524.

Pemble S, Schroeder KR, Spencer SR, Meyer DJ, Hallier E, Bolt HM, Ketterer B and Taylor JB (1994) Human glutathione S-transferase theta (GSTT1): cDNA cloning and the characterization of a genetic polymorphism. Biochem J 300:271276.

Raunio H, Husgafvel-Pursiainen K, Anttila S, Hietanen E, Hirvonen A and Pelkonen O (1995) Diagnosis of polymorphisms in carcinogen-activating and inactivating enzymes and cancer susceptibility - A review. Gene 159:113-121.

Roff DA and Bentzen P (1989) The statistical analysis of mitochondrial DNA polymorphisms: $\chi^{2}$ and the problem of small samples. Mol Biol Evol 16:539-545.

Rossini A, Rapozo DCM, Amorim LMF, Macedo JMB, Medina R, Neto JFN, Gallo CVM and Pinto LRF (2002) Frequencies of GSTM1, GSTT1, and GSTP1 polymorphisms in a Brazilian population. Genet Mol Res 1:233-240.

Stephens M, Smith N and Donnelly P (2001) A new statistical method for haplotype reconstruction from population data. Am J Hum Genet 68:978-989.

Associate Editor: Francisco Mauro Salzano 